\title{
The Development of Storytelling Guide Model for Teachers at Early Childhood Education
}

\author{
Arman Agung ${ }^{1 *}$, Ismail Tolla², Sulaiman Samad ${ }^{3}$ \\ ${ }^{1}$ Department of Education, Universitas Negeri Makassar \\ Jln. Bonto Langkasa Kampus Gunung Sari Baru Program Pascasarjana, Makassar, Indonesia \\ Email: armanagung.drc [AT] gmail.com \\ ${ }^{2}$ Department of Education, Universitas Negeri Makassar \\ Jln. Bonto Langkasa Kampus Gunung Sari Baru Program Pascasarjana, Makassar, Indonesia \\ Email: ismail.tolla [AT] yahoo.com \\ ${ }^{3}$ Department of Education, Universitas Negeri Makassar \\ Jln. Bonto Langkasa Kampus Gunung Sari Baru Program Pascasarjana, Makassar, Indonesia \\ Email: essamad [AT] unm.ac.id
}

\begin{abstract}
All Early Childhood Education teachers realize that storytelling is one of the character-building methods for early childhood. It is rarely applied because storytelling is difficult; they cannot act and imitate voices or sounds. Although there are capable teachers, they are still amateur. Therefore, teachers need a storytelling guide that is valid, practical, and effective. In this study, teachers who were respondents came from four Early Childhood Education units in Palu City, Province of Central Sulawesi. Data was obtained through literature and field studies by collecting theories from relevant research through observation, interviews, and questionnaires. Data collection was carried out in a natural condition and analyzed qualitatively in the form of descriptive data. The results of the study stated that was valid, practical, and effectively used by teachers, that was an increase in knowledge, attitudes, and skills in storytelling after using the guide of the development model.
\end{abstract}

Keywords--- Guide, Storytelling, Early Childhood Education Teachers

\section{INTRODUCTION}

In general, in Indonesia, including the city of Palu, what is called early childhood as it is known by Early Childhood Education teachers and various groups involved in the world of early childhood education are children aged 0 - 6 years. Preschool education (Early Childhood Education), both public and private, and early grade elementary schools (SD) who sit in grades 1,2, and 3 with ages $6-8$ years [1].

Early childhood is a child at an age that is very effective for the development of various potentials and values, attitudes and behaviours that can build children's morals. In the process of early childhood education, this development effort can be carried out in various dimensions, including character education through play and storytelling activities [2]. These activities are related to cognitive abilities and mental, social and emotional readiness to shape character, one of which is obtained through playing and storytelling. Therefore, to achieve optimal results, the implementation must be done in a more interesting, varied, fun way, and last but not least, its effectiveness [3].

Educational institutions called schools, burdened by society with a double responsibility, contribute to academic achievement and their character. In fact, character education at the school level is the main thing and has become a trending topic for education observers in Indonesia. This responsibility burden should actually be implemented at the preschool level (Early Childhood Education). Therefore, through research from various professionals who are competent in their fields, a method is created that can be fun stimulation, which gives children the freedom to explore through play, storytelling, or other activities to instil character in children as a form of children's personality attitudes at the level. Early Childhood Education [4].

Educators have a responsibility to produce a generation with character, culture and morals. Teachers have a very big role in shaping children's character attitudes. According to Subiyantoro (in [5]), psychologists say that childhood is a time full of imagination. Children have a more diverse imagination than adults. Moreover, when children are presented with stories or fairy tales and when playing a character from a story in role-playing activities, their imagination will turn on their fantasy power so that it seems as if they become the person they play. Imagination is the power of thought to imagine (daydream) an event based on someone's reality or experience. Storytelling is very good for the development of children's imagination and rhythmic feel of the child's left brain for the development of children's character [6]. 
It can strengthen emotional bonds and communication between parents, teachers/tutors, and children through storytelling activities. Besides that, what is no less important is that storytelling activities, besides being able to instil moral values, can also increase the ability of three important aspects for early childhood, namely cognitive, affective and motoric aspects. In the cognitive aspect, fairy tales will improve children's imagination and creativity abilities. When children listen to fairy tales, they will be stimulated to read the story in his mind (theater of mind). Children can visualize themselves in stories or fairy tales that they hear. With his version, he can imagine what the characters are like and how and the situations and conditions that exist in the fairy tale automatically. In the affective aspect, usually, fairy tales will arouse children's emotions according to the storyline in the fairy tale. In such conditions, fairy tales will have the potential to be constructive and effective in developing various values, ethics and character, even empathy in early childhood, for example, the values of honesty, humility, solidarity, hard work, respect and obedience to parents, including in instilling good habits, for example, the importance of eating vegetables and fruits, brushing teeth after eating and so on, which at a later stage will affect the development of his personality. Meanwhile, the psychomotor aspects will be trained when children can be invited to imitate various forms and styles or behaviour of characters in the story. Fairy tales will be easier and faster to give a positive effect than through advice, especially through threats, especially with punishment [7].

Based on initial observations in the field, a phenomenon was found in several Early Childhood Education units in Palu City. In fact, the findings show that there are several negative characters in children. The various behaviours found in the field are as follows: (1) many children do not want to follow the rules, (2) act at will based on their own will so that they can disturb other children, one of the simple behaviours that appear is not wanting to share toys with friends or grabbing friends' toys, (3) don't want to keep toys in their place, (5) are not disciplined in using time, (6) don't want to queue, (7) don't dare to appear, and so on. [8] in their research entitled fairy tales as a medium for character planting in early childhood. The results showed that fairy tales are very effective to be applied to early childhood. The need for habituation and good examples to foster children's character by storytelling can instil character values. Research conducted by [9] states that the fairy tale method can be used as a medium for shaping the personality and morality of early childhood, through the fairy tale method will provide learning experiences for early childhood.

Around mid-2018, namely during the implementation of the initial research (needs analysis), the researcher obtained information based on the results of observations in several Early Childhood Education units in Palu City, that almost all teachers in the education unit could not tell the story because they had not been able to portray different character characters. In the story, they cannot at all imitate voices or sounds like a storyteller, as well as the relatively flat intonation/dynamics of sound and so on, which in essence they think storytelling is difficult and cannot do it arbitrarily. Only certain people and those who have talent in that field. This phenomenon is what motivates the development of this model, including; (1) Early Childhood Education teachers realize that storytelling is a method of shaping early childhood character, but it is rarely done in educational units; (2) Storytelling is rarely / not done in Early Childhood Education units because storytelling is difficult, teachers cannot imitate voices or sounds like professional storytellers; (3) Most Early Childhood Education units do not carry out storytelling activities on the grounds that there are no teachers/tutors who are capable of storytelling, but they want storytelling activities to be carried out in their educational units; (4) There are Early Childhood Education units that carry out storytelling activities using the reading method but are still in the category of perfunctory, casual, or as much as possible; (5) Early Childhood Education teachers need references or guidelines that are valid, practical, and effective.

Based on the results of the analysis of these various phenomena, the writer believes that in order to get the optimal benefits of fairy tales as the results of research by experts, it is a problem of the teacher's ability to tell stories first that needs to be solved by finding the right solution. Therefore, in this study, the author wants to create a guide as a treatment that contains a series of steps and specific steps in storytelling activities for Early Childhood Education teachers, which, although only by using the "reading" technique, have an effect on early childhood as the target of their students. It can be more optimal, even equivalent to the effect of a fairy tale delivered by a reliable storyteller. Therefore, the author is encouraged to research "Model Development of Storytelling Guide for Early Childhood Teachers".

\subsection{Problem Formulation}

Based on the research background above, the researcher's problem formulation are:

1. What is the description of the needs of Early Childhood Education teachers for the development of a storytelling guide model?

2. What is the design description of a storytelling guide model for Early Childhood Education teachers in improving their ability to tell storytelling in early childhood?

3. What is the level of validity and practicality of storytelling guides for Early Childhood Education teachers in improving their ability to tell storytelling in early childhood?

4. What is the level of effectiveness of the application of storytelling guidelines for early childhood teachers in improving storytelling skills in early childhood? 


\subsection{Research Objectives}

Based on the formulation of the problem above, the objectives of this study are:

1. To get an idea of how early childhood teachers need to develop a storytelling guide model.

2. Obtain an overview of the design of a storytelling guide model for early childhood teachers in improving their ability to tell storytelling in early childhood.

3. Produce a valid and practical guide for early childhood teachers in improving their ability to tell storytelling in early childhood.

4. Creating an effective guide for early childhood teachers in storytelling activities in early childhood.

\subsection{Hypothesis}

As a rule of thumb in guiding the development of the model from the early to the tangible form of a guideline, a chart is drawn up as follows: 


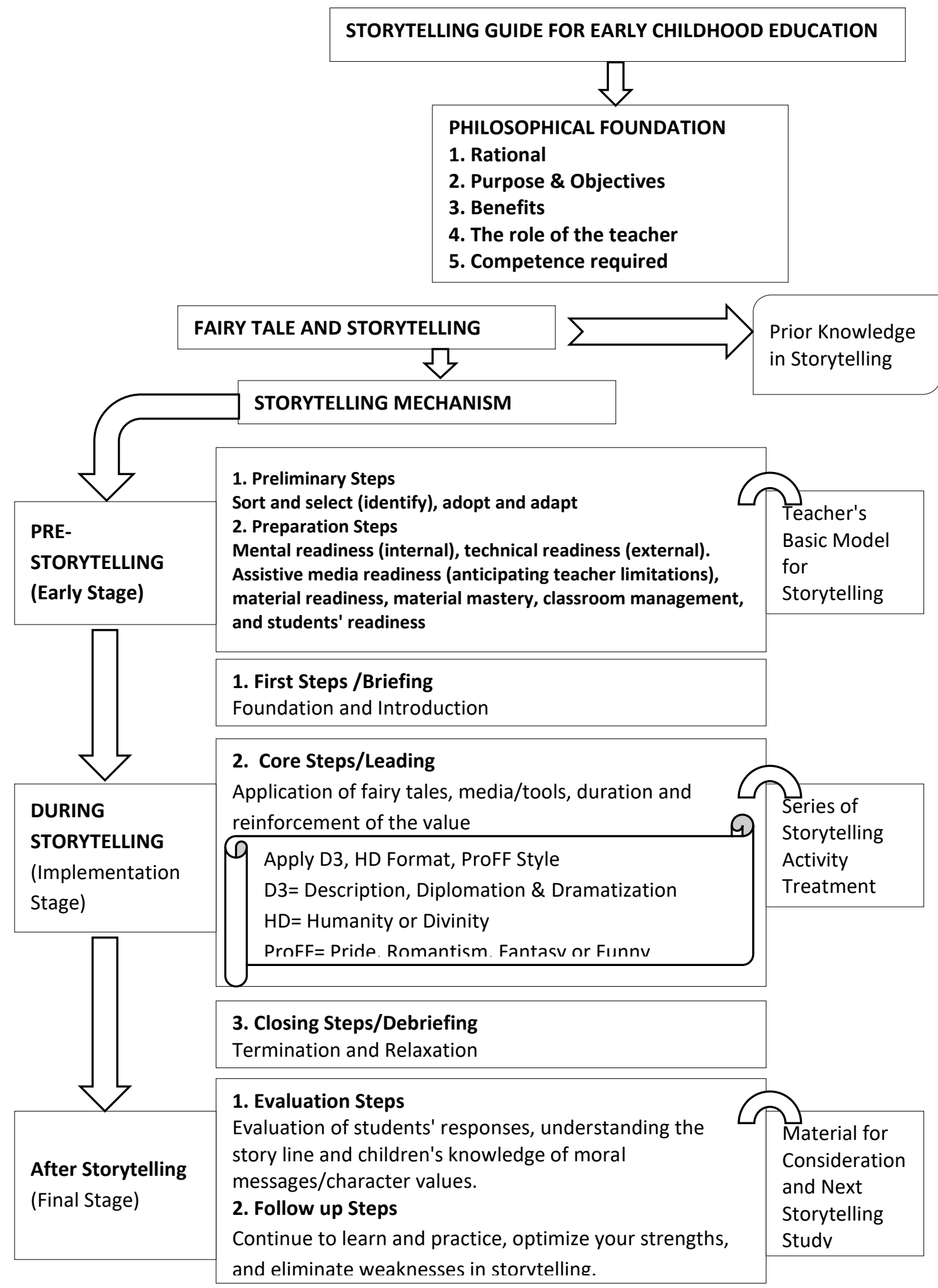

Fig. 1 Hypothetical Design Chart

Model of a Storytelling Guide for Early Childhood Teachers

Based on the results of observations and literature review, including the results of discussions with several fairy tale practitioners, the hypothetical model is designed according to the design stage of the guidebook model. Academically validated guidelines that will be produced later are one of the outputs of the development of this model, while the increase in teacher storytelling skills in the Early Childhood Education unit can be called the outcome. 
An overview of the design of the content of the storytelling guide model for early childhood teachers that will be developed, which contains: 1) a philosophical foundation that contains, rational or something that motivates or motivates the need for Early Childhood Education teachers to have storytelling skills, the aims and objectives of the guide, the benefits, what is the role of the teacher and competence; 2) fairy tales and storytelling, namely containing basic knowledge of fairy tales and storytelling; 3) easy and practical storytelling contains storytelling mechanisms ranging from prestorytelling, when telling storytelling, to post-storytelling; 4) closing, which contains the conclusions and suggestions and the author's curriculum vitae.

The Pre stage of storytelling is the initial stage, which consists of an initial step and a preparatory step. The initial step contains foundation techniques followed by introductory activities or storytelling intro activities. Preparatory steps contain mental readiness (internal), technical readiness (external), readiness of assistive media (anticipating teacher limitations), material readiness, mastery of material, classroom arrangement, and readiness of students (early childhood). These two steps are the knowledge, attitudes, and skills that are the basic assets for teachers that must be possessed or prepared to be applied at the next stage. When storytelling is the implementation stage of the storytelling activity which contains three main steps, namely, a briefing step, a leading step, and a debriefing step. These three things are a series of core treatments in storytelling activities.

The core step is when presenting the story by paying attention to the duration by the teacher including the application of tools or assistive media that are used as a solution to the teacher's limitations (imitation of voices or sounds), which ends with the closing steps, namely termination (techniques to end the story) and relaxation. In the implementation of fairy tales based on the keyword "Apply D3, HD Format, PRoFF style". Apply D3, which stands for: Description (describe in an interesting way), Diplomation (logical negotiation in conflict), and Dramatization (make it as drama as possible), whether in the frame of Humanity or Divinity, and understand the storytelling style abbreviated as "PRoFF" ": Pride (bravery / heroism), Romanticism (touching stories), Fantasy (stories that arouse the imagination), or Funny (amusing / witty entertainment stories).

Furthermore, after storytelling, the final stage of storytelling activities has two steps: the evaluation and the follow-up step. The evaluation step consists of evaluating students 'responses, students' understanding of the storyline and their knowledge of the moral messages or character values contained in the fairy tales. Meanwhile, the follow-up steps are continuing to learn and practice and make efforts to optimize all the advantages possessed and eliminate all the weaknesses of the teacher in storytelling.

\section{RESEARCH METHODS}

The research carried out is a type of research development (Research and Development) using qualitative methods which are the basis for this research to obtain information or get an overview, how to develop a storytelling guide for Early Childhood Education Teachers, using the ADDIE development model which has five stages of implementation, namely analyzing, designing, developing, implementing, and evaluating.

\subsection{Population and Research Sample}

The population of this study were teachers in early childhood education units in the city of Palu. The number of education units registered in the Education Primary Data is 278 units, with a ratio of 2 to 5 teachers for each unit. Each teacher educates 10-15 students. The research sample was taken from the teacher population of the early childhood education unit, namely:

- Teachers in the Early Childhood Education unit TK Negeri Pembina Utara Palu in Palu City;

- Teachers at Mutiara Hati Integrated Early Childhood Education units in Palu City;

- Teachers at the Early Childhood Education Najadi Topande unit in Palu City, and

- Teachers at the Putra Kaili Permata Bangsa Early Childhood Education unit in the city of Palu.

\subsection{Data collection technique}

Data collection is carried out in a natural setting (natural conditions), data sources through observation, interviews, questionnaires and documentation. Data collection techniques were carried out by means of observation and questionnaires. The observation sheet is used to determine the extent to which the storytelling method is applied by the teacher, character building by the teacher in learning, and to record children's responses in the process of storytelling activities. A questionnaire or questionnaire is a number of written questions that are used to obtain information from respondents in the sense of reports about their personalities or things they know about storytelling.

\subsection{Data analysis technique}

The data analysis used in this research is descriptive qualitative analysis, which describes completely and accurately the data obtained from various sources to achieve the research objectives, then analyzed to explain the validity of the 
storytelling guide model developed using data that has been obtained through observation, interviews, and needs analysis, and teacher questionnaires.

\section{RESEARCH RESULTS AND DISCUSSION}

\subsection{Research result}

The results of the needs analysis inspired the development of a storytelling guide model for early childhood education teachers in four Early Childhood Education units which were used as research locations in Palu City and after going through field trials. The data obtained from the analysis of the needs of 4 Early Childhood Educations in Palu City with 16 respondents, namely four people each from the Early Childhood Education TK Negeri Pembina Utara Kayumalue Early Childhood Education unit in Palu City, Mutiara Hati Integrated Early Childhood Education unit in Palu City, the Early Childhood Education Najadi Topande unit in Palu City. Palu City, and in the Putra Kaili Permata Bangsa Early Childhood Education unit in Palu City. Researchers asked questions to obtain information on product needs with a total of 14 questions; for 16 respondents from 4 Early Childhood Education units, the value was 817 while the total value of respondents was 896 with the highest value was 56 . So that the percentage value was obtained by calculating $817: 896 \mathrm{x}$ $100 \%=91.18 \%$ with criteria "Really Need".

The analysis of the principal's needs with 14 questions for 4 respondents (school principals) from 4 Early Childhood Education units, the value was 224. Meanwhile, the respondents' score was 219 with the highest score of 56 and the lowest score of 14 . So that the percentage value was obtained by calculating 219: 224 x 100 =97.76\% with criteria "Really Need". When combined with the results of the teacher's response, the mean value is $94.47 \%$ with the criteria "Really Need".

Validation is carried out by an expert or expert as a validator of the handbook made. Handbook validation is carried out by linguists, design and material experts. From the results of the validation carried out by the expert team and after being revised by the researcher according to the validator's instructions and suggestions, the guidebook produced in this study was declared valid.

The series of practical implementation trials was carried out for three days by gathering teachers as respondents accompanied by the principal of each of the four Early Childhood Education units who were used as samples in the study. The results of the practicality test were based on the observations of researchers with 16 questions for 16 respondents, with a value of 843 . While the total value of respondents was 960 with the highest value of 64 and the lowest value of 15 . So that the percentage value was obtained by calculation, namely $(843: 960)$ x $100 \% .=87.81$ with "Practical" criteria. Furthermore, based on the observations of the research assistant, the total value was 846 , so that the percentage value was obtained by calculation, namely (850: 960) x $100 \%=88.13 \%$ with the criteria "Very Practical".

In addition to assessing respondents using observation instruments, the practicality assessment of the guide model was also measured through an interview test with each teacher who was the research respondent, namely 16 people, using an interview format consisting of 5 questions with 4 ranges of answer values, namely: 1 (Disagree), 2 (Disagree), 3 (Agree) and, 4 (Strongly agree). The results obtained are $(298: 320)$ x $100 \%=93.12 \%$ with the criteria "Very Practical".

The effectiveness of this model is measured by observing the responses of students when storytelling activities are carried out by the teacher. It is said that it is effective when using the model of development results guidance, there is a good response from students. This product effectiveness test is carried out before finishing the Storytelling Guide Book product. The trial of the effectiveness of the guide was carried out in two trial groups, the first was a small group trial in each unit and a large group which was a combined class of small groups.

Based on the analysis of the effectiveness test instrument in small groups, namely groups of each unit consisting of one teacher who has relatively mastered the content and is able to better practice the contents of the guidebook (the teacher who has the highest / best score in his / her group / unit), as well as one class of students in the unit. The results obtained are; Mutiara Hati Integrated Early Childhood Education unit, to the response of 17 children, namely (293: 340) x 100\% = 86.17\% (Very Good), the Putra Kaili Permata Bangsa Early Childhood Education unit to the response of 15 children, namely (260: 300) x 100\% = $86.67 \%$ (Very Good), the Early Childhood Education TK Pembina unit to the response of 20 children, namely (349: 400) x 100\% $=87.25 \%$ (Very Good), and the Early Childhood Education Najadi Topande unit to the response of 15 children, namely (263: 300) x $100 \%=87.67$ (Very Good). If averaged, the value is $86.94 \%$ with the criteria "Very Good".

The effectiveness test was also carried out in large groups, namely the merger of 4 units that became the research location by gathering all the teachers who were respondents together with the principal, each presenting 10 students from each unit, a total of 40 children. From these activities the results obtained (334: 100) x $100=83.5 \%$ with the criteria "Very Good". 


\subsection{Discussion}

The development of this model is an alternative answer to the problems of teachers in Palu City related to their very minimal storytelling ability. The need for this research to be supported by various previous studies; The teacher's storytelling ability does not seem varied and unattractive [10]; Teachers are expected to have the ability to tell storytelling as one of the methods used in classroom learning [11]; Teachers must have the ability to tell stories so that children are interested in learning and not boring [8]. In essence, it states that there needs to be a guide or guide for teachers in storytelling.

The initial process of this research was carried out by testing the validity of the product and testing the validity of the instrument through expert judgment, followed by testing its practicality and effectiveness, as well as making revisions at each trial level so that the resulting product was tested properly. The subject of this research is specifically for teachers, while the sample of this research is all personnel in the education unit. The object of research is a Storytelling Guide for Early Childhood Education Teachers. The students are part of measuring the effectiveness of the research object. The final result of this research is to produce a product in the form of a valid, practical and effective storytelling guide for Early Childhood Education teachers. This guide can serve as a reference which is an alternative solution for Early Childhood Education teachers to be able to tell story well with optimal results without having the talents and talents as well as the ability to imitate voices / sounds like a professional storyteller.

The storytelling guide text at the beginning contains a philosophical foundation as an introduction which contains the rational urgency of preparing the guidelines. In the main part, consists of pre (before), during and after (after) storytelling, which is the core of a practical and effective guide in terms of storytelling. This guide is also accompanied by examples of fairy tales that have been adopted and adapted, and are ready to be presented.

The pre-storytelling section reveals a knowledge of the technique of sorting and selecting and adoption and adaptation. The sort-and-select technique is concerned with screening fairy tales that are simple but contain good and unambiguous moral messages. Adoption and adaptation techniques that are useful for facilitating students' understanding of fairy tales conveyed by the teacher, will also bring closer emotional relationships between teachers and early childhood when teachers tell stories. Furthermore, in the preparation step, contains about how teachers prepare mentally so that teachers have psychic readiness and strength, technical preparation to anticipate teacher weaknesses who cannot imitate voices or sounds such as professional storytellers, communication skills to improve teacher performance, techniques prepare material so that teachers can tell storytelling without having to memorize fairy tales, mastery of the material, classroom arrangement and children's readiness, all of which will make the teacher appear well and full of confidence when telling stories to students.

In the Storytelling Time section, which is Initial Activity, there is a step called Foundation, which will encourage the birth of the best action we can take if done correctly. In the section on Application of Fairy Tales, besides containing instructions and mechanisms for describing fairy tales and anticipating situations when the teacher tells stories in front of the class. Also contains the application of assistive tools / media as a solution to the limitations of teachers and the keyword "apply D3, HD format, ProFF style". Apply D3 which stands for: Description (describe it in an interesting way), Diplomation (logical negotiation in conflict), and Dramatization (make it as rhythmic as possible). HD format, whether in the frame of Humanity (humanity) or Divinity (divinity / spirituality), and understand the storytelling style according to the storyline, namely one of the abbreviations "PRoFF": Pride (valor/heroism), Romanticism (touching story), Fantasy (stories that arouse the imagination) or Funny (humor).

The closing section consists of "value strengthening suggestions", namely steps aimed at emphasizing the meaning of moral messages, reviewing the moral messages of fairy tales in a deeper way by relating them to children's daily lives. This is done while imitating a character's voice or sentence, singing (language and art), and imitating the movements of a story character, inviting children to clap their hands (fine and gross motoric). Furthermore, termination and relaxation are carried out.

The post storytelling section contains evaluation steps in the form of self-assessment which will control the quality of the success of teachers as storytellers by using students' response indicators and the extent to which they understand the storyline and their knowledge of the moral messages of fairy tales. In addition to the evaluation, a follow-up was also carried out for the teacher to continue to practice improving flight hours to optimize their advantages and eliminate their weaknesses in storytelling activities based on the evaluation results.

\section{CONCLUSION}

Based on the results of the research and discussion described, the following conclusions were formulated:

1. The need to develop a storytelling guide for Early Childhood Education teachers is based on the awareness that storytelling can help develop children's character, but the method that is done by early childhood teachers in Palu is only telling stories and reading. This is because there are no guidelines or guidelines that can be followed.

2. A storytelling guide for Early Childhood Education teachers which is designed to consist of a philosophical foundation, namely rationality, goals, benefits, the role of the teacher, and the competencies required. While the 
implementation mechanism or syntax consists of three important stages, namely pre storytelling activities (early stage), storytelling time (implementation/core stage), and post storytelling (final stage).

3. The developed storytelling guide for Early Childhood Education teachers has a valid/adequate content validity and practicality level.

4. A storytelling guide for early childhood teachers has an effective level for the ability of Early Childhood Education teachers to tell stories.

\section{RECOMMENDATIONS}

With the presence of a storytelling guide that has been scientifically reviewed, it is hoped that teachers who do not have the talent and ability to tell storytelling, such as professional storytellers, will use this guide as a reference point in storytelling activities.

\section{REFERENCES}

[1] Priyanto A. PENGEMBANGAN KREATIVITAS PADA ANAK USIA DINI MELALUI AKTIVITAS BERMAIN. Jurnal Ilmiah Guru Caraka Olah Pikir Edukatif [Internet]. 2014 [cited 2021 Jun 4];0(2). Available from: https://journal.uny.ac.id/index.php/cope/article/view/2913

[2] Hafida N, Jadid UN. PEMBENTUKAN KARAKTER PEDULI DAN BERBUDAYA LINGKUNGAN BAGI PESERTA DIDIK DI MADRASAH MELALUI PROGRAM ADIWIYATA. 2018;8:22.

[3] Polina L, Pramudiani P. Pembelajaran Karakter Melalui Media Dongeng pada PAUD Formal Binaan I dan Binaan III Ciracas Jakarta Timur. Jurnal Solma. 2018;7(2):215-24.

[4] juwita W. Urgensi Bermain Sebagai Stimulasi Perkembangan Otak dan Solusi Mengatasi Kekerasan (Child Abuse) dalam Pertumbuhan dan Perkembangan Anak. QAWWAM. 2018 Jun 1;12(1):40-60.

[5] Habsari Z. DONGENG SEBAGAI PEMBENTUK KARAKTER ANAK. BIBLIOTIKA : Jurnal Kajian Perpustakaan dan Informasi. 2017 Apr 5;1(1):21-9.

[6] Harahap R. Pengembangan Imajinasi Anak Melalui Dongeng. In: Prosiding Seminar Nasional Pendidikan Bahasa dan Sastra Indonesia [Internet]. Medan: Unimed; 2018 [cited 2021 Jun 4]. p. 49-55. Available from: http://digilib.unimed.ac.id/38757/1/6.\%20Fulltext.pdf

[7] Aziz F, Nurjanah F, Sari DP. AKTUALISASI TTB (TEORI TAKSONOMI BLOOM) MELALUI DRAMA KEPAHLAWANAN GUNA PENANAMAN PENDIDIKAN KARAKTER PADA PESERTA DIDIK. In: FKIP ePROCEEDING [Internet]. Jember: Program Studi Pendidikan Bahasa dan Sastra indonesia FKIP; 2017 [cited 2021 Jun 4]. p. 715-24. Available from: https://jurnal.unej.ac.id/index.php/fkip-epro/article/view/4950

[8] Fitroh SF, Sari EDN. DONGENG SEBAGAI MEDIA PENANAMAN KARAKTER PADA ANAK USIA DINI. Jurnal PG-PAUD Trunojoyo : Jurnal Pendidikan dan Pembelajaran Anak Usia Dini. 2015 Oct 28;2(2):95-105.

[9] Yuhelmi Y. PENDIDIKAN KARAKTER ANAK USIA DINI MELALUI STRATEGI MENDONGENG CERITA BUDAYA DAERAH MINANGKABAU. Pedagogi: Jurnal Ilmu Pendidikan. 2014 Nov 1;14(2):55-61.

[10] Lusiana D, Lestari W. INSTRUMEN PENILAIAN AFEKTIF PENDIDIKAN KARAKTER BANGSA MATA PELAJARAN PKN SMK. Journal of Research and Educational Research Evaluation [Internet]. 2013 [cited 2021 Jun 4];2(1). Available from: https://journal.unnes.ac.id/sju/index.php/jere/article/view/1330

[11] Fitriyyah D. PENDIDIKAN KARAKTER MELALUI KEGIATAN MENDONGENG DI TK ABA KARANGDUWUR DAN TK MASYITHOH PETANAHAN KABUPATEN KEBUMEN. Jurnal Pendidikan Agama Islam. 2014 Dec 1;11(2):169-84. 